\title{
Alzheimer disease and platelets: how's that relevant
}

\author{
Silvia Catricala ${ }^{1}$, Mauro Torti ${ }^{2}$ and Giovanni Ricevuti ${ }^{3 *}$
}

\begin{abstract}
Alzheimer Disease (AD) is the most common neurodegenerative disorder worldwide, and account for $60 \%$ to $70 \%$ of all cases of progressive cognitive impairment in elderly patients. At the microscopic level distinctive features of $A D$ are neurons and synapses degeneration, together with extensive amounts of senile plaques and neurofibrillars tangles. The degenerative process probably starts 20-30 years before the clinical onset of the disease. Senile plaques are composed of a central core of amyloid $\beta$ peptide, $A \beta$, derived from the metabolism of the larger amyloid precursor protein, APP, which is expressed not only in the brain, but even in non neuronal tissues. More than 30 years ago, some studies reported that human platelets express APP and all the enzymatic activities necessary to process this protein through the same pathways described in the brain. Since then a large number of evidence has been accumulated to suggest that platelets may be a good peripheral model to study the metabolism of APP, and the pathophysiology of the onset of AD. In this review, we will summarize the current knowledge on the involvement of platelets in Alzheimer Disease. Although platelets are generally accepted as a suitable model for $A D$, the current scientific interest on this model is very high, because many concepts still remain debated and controversial. At the same time, however, these still unsolved divergences mirror a difficulty to establish constant parameters to better defined the role of platelets in AD.
\end{abstract}

Keywords: Alzheimer disease, Platelets, Amyloid precursor protein.

\section{Introduction}

Molecular features and pathogenesis of alzheimer disease Alzhemeir's Disease (AD) is a chronic progressive neurodegenerative disorder characterized by a devastating cognitive and memory decline. It is the most common cause of dementia in the elderly, affecting about 26 million people worldwide, and whose prevalence has been calculated to quadruple by 2050 [1-3].

The first neuropathological case of a patient affected by $\mathrm{AD}$ was described over 100 years ago, and the presence of senile plaques and neurofibrillary tangles in the brain, two major hallmarks of AD, were described [4].

Senile plaques are characterized by the abnormal accumulation of amyloid $\beta$-peptide $(A \beta)$ in the form of $\beta$-plated sheet fibrils, in nervous tissues and in blood vessels [5]. $A \beta$ is a $4 \mathrm{KDa}$ hydrophobic molecule included into a much larger membrane glycoprotein, named amyloid precursor protein, APP [6], from which it is released upon limited proteolysis. $\mathrm{A} \beta$ can exist as monomer, dimer, oligomer, protofibril, and

\footnotetext{
* Correspondence: giovanni.ricevuti@unipv.it

${ }^{3}$ Department of Internal Medicine and Therapeutics, Section of Geriatrics, University of Pavia, ASP-IDR S.Margherita, Via Emilia 12, Pavia 27100, Italy Full list of author information is available at the end of the article
}

fibrillar aggregates [7]. The propensity to self-association of $A \beta$ seems to depend on the peptide's primary sequence. Indeed the $A \beta 42$, which makes up less than $10 \%$ of total $A \beta$, is more prone to aggregate than the more abundant A $\beta 40$ [8].

Neurofibrillar tangles are mainly composed by a cytoskeletal microtubule-associated protein, called tau, that becomes hyperphosphorylated, dissociates from microtubules, and self-aggregates in the cytosol to form paired helical filaments. However, since hyperphosphorylated tau seems to be present also in other neurodegenerative diseases, and since all the currently identified genetic mutations responsible for $\mathrm{AD}$ invariably result in increased formation of fibrillogenic $A \beta$, the amyloid cascade hypothesis is the most widely accepted event for the pathogenesis of $\mathrm{AD}[9]$.

Two forms of $\mathrm{AD}$ have been described: a sporadic or senile form, and a familial (FAD) or presenil form. The former one develops in $95-98 \%$ of cases $[10,11]$, while the familial cases are limited to only $2-5 \%$.

The onset of the sporadic form of AD typically occurs in patients after 65 years of age old, meanwhile the onset of familial form occurs generally before this age. No genes 
are directly responsible for the onset of the sporadic AD, but an association with polymorphisms of the gene ApoE have been reported [12,13].

In nervous system APP plays major roles in synaptogenesis and synaptic plasticity. It is expressed in human brain, cerebrospinal fluid [14], kidney, spleen, heart and adrenal tissues [15], but it also is expressed in peripheral circulating cells as platelets [16]. App gene contains 19 exons, and at least 10 different mRNA can be generated by alternative splicing. The most common isoforms inlcude APP695, predominantly expressed in neuronal tissues, and the isoforms APP751 and APP770 achieved by the insertion of a serine protease inhibitory domain of the Kunitz type family [17], which are abundantly expressed in non-neuronal cells [18-20].

APP is a type I transmembrane glycoprotein with a large extracellular N-terminal domain, and a short cytoplasmatic C-terminal domain [21]. APP proteolitic processing is complex and results from the action of two alternative pathways that involve either $\alpha$-secretase (non-amyloidogenic pathway) or $\beta$-secretase (amyloidogenic pathway), besides the $\gamma$-secretase complex $[22,23]$. Only the amyloidogenic pathway generates and releases A $\beta$ peptide, composed by $40-42$ aminoacidic residues [24], while in the non-amyloidogenic pathway sAPP $\alpha$ which may have neuroprotective effects, is produced [25].

\section{Platelets and alzheimer disease}

Anucleated blood platelets can be considered a peripheral available model to study those metabolic mechanisms, occurring in the central nervous system and related to $\mathrm{AD}$. Moreover, several intracellular signaling pathways, important for platelet activation involve essential molecules, that have also been described to modulate APP processing $[26,27]$. The major important platelet agonist, thrombin, actives platelets by binding to membrane receptors PAR1, PAR4, and glycoprotein GPIb-IX$\mathrm{V}$, which is also able to interact with von Willebrand Factor (vWF). Other important platelets agonists include collagen that binds to integrin $\alpha 2 \beta 1$ and the glycoprotein GPVI; ephinephrine, tromboxane A2, and ADP, that bind to specific G protein-coupled receptors. Platelet agonists activate specific signaling pathways, involving different molecules and enzymes, which typically lead to a transient increase of intracellular $\mathrm{Ca}^{2+}$ concentration. The final step of platelet activation is the inside-out stimulation of $\alpha \operatorname{IIb} \beta 3$ integrin activation, which binds fibrinogen and triggers an outside-in signaling pathway that promotes stable and irreversible aggregation (Figure 1).

Platelets also store and release neurotransmitters, such as serotonin, glutamate and dopamine [28,29], and some neuron-related proteins such as $\mathrm{N}$-methyl-d-aspartate, NMDA, receptors.
Therefore, many researchers have focused their attention on platelets as a key peripheral element to understand the pathogenesis of $\mathrm{AD}$.

Animal models are often a valuable tool in basic and biomedical research, and several studies on mice, Drosophila melanogaster, Caenorhabditis elegans and two types of fish, the sea lamprey and the zebrafish [30] have provided essential insights into the molecular mechanism of $\mathrm{AD}$. Transgenic mice are also extremely useful to investigate platelet function, however so far no reports have addressed the platelet biology in the most common murine model for $\mathrm{AD}$, such as the trangenic $\mathrm{Tg} 2576$ [31,32] or the PD-APP transgenic mice [33,34].

\section{The metabolism of amyloid precursor protein in platelets}

Human platelets contain high levels of APP, which may contribute to more than $90 \%$ of the circulating APP [20]. Platelets show concentrations of APP isoforms equivalent to those found in brain [15], but the expression pattern is different: the isoform APP695, which is the most abundant in neuronal tissue, is nearly undetectable in platelets, where the predominant isoforms are APP770 [16] and APP751 [35].

Platelet APP may represent the major source of A $\beta$ detected in whole blood [36], and recent findings have suggested that platelet APP metabolism might also contribute to the accumulation of $A \beta$ in the brain and its vasculature through the blood brain barrier $[37,38]$.

Intact APP is present on the platelet plasma membrane, and is encoded by platelet mRNA [39]. In fact platelet APP is synthesized by the platelet precursor, the megakaryocyte, in the bone marrow, rather than being the result of platelet uptake of circulating APP [16]. Platelets also express all the required enzymatic activities $(\alpha, \beta$ and $\gamma$-secretases) to produce all the APP metabolites (sAPP $\alpha$ sAPP $\beta$ and A $\beta$ ), that can be stored into intracellular granules [40]. Proteolytic cleavage of platelet APP may occur both within intracellular organelles of the secretory pathway, and on the platelets' surface [41,42]. sAPP $\alpha$ and $\mathrm{A} \beta$ peptides can be stored in $\alpha$-granules and released by exocytosis upon platelet activation by thrombin or collagen, which induce $\mathrm{Ca}^{2+}$-dependent degranulation [16,20,40-42].

\section{Role of amyloid precursor protein in platelets}

The physiological role of APP and of its metabolites in platelets is not yet well understood. The full-length APP may act as a receptor on the platelet surface, thanks to the cysteine-rich domain, KPI [14,43]; platelet APP has also been proposed to be crucial in the regulation of intracellular $\mathrm{Ca}^{2+}$ concentration [44].

Several evidence indicate that platelet APP may play a role also in blood coagulation thanks to KPI domain, inhibiting the activity of the blood coagulation factors IXa, $\mathrm{XIa}$, and Xa $[45,46]$. Some studies indicate a physiological 


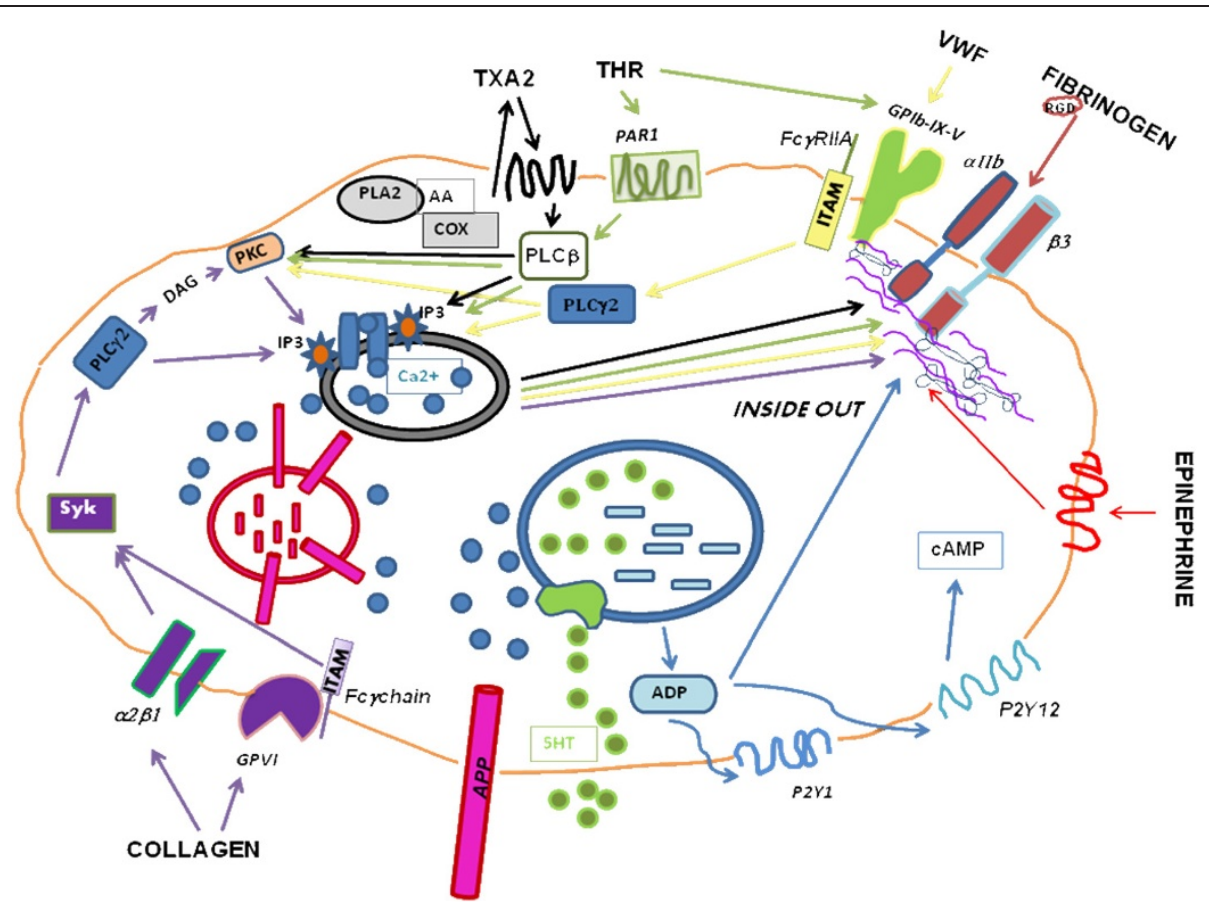

Figure 1 Principal platelet membrane receptors and signal transduction pathways. Different receptors are stimulated by various agonists, almost converging in increasing intracellular $\mathrm{Ca}^{2+}$ concentration. Platelet activation induces an inside out signaling pathway that active $a_{\| b} \beta_{3}$ integrin. The subsequently link of $a_{\| b} \beta_{3}$ with fibrinogen lead to an outside in signaling pathway that promotes irreversible aggregation. Abbreviations: TXA2, tromboxane A2; THR, thrombin; PAR1, protease-activated receptor-1; WWF, Von Willebrand Factor; RGD, arginine, glycine, aspartic acid; GPIb-IX-V, glycoprotein Ib-IX-V; FcyRIIA, cristallizable fragment $\gamma$ receptorlIA; $a_{\| b} \beta_{3}, a_{\| b} \beta_{3}$ integrin; cAMP, cyclic adenosin monophosphate; P2Y12, P2Y12 receptor; P2Y1, P2Y1 receptor; ADP, adenosin diphosphate; 5HT, 5-hydroxytryptamine; APP, amyloid precursor protein; GPVI, glicoprotein VI; a2 $\beta 1$, a2 $\beta 1$ integrin; Syk, Syk tyrosin kinase; PLC 2 , phospholipase $\gamma 2 ;$ DAG, diacilglicerol; PKC, protein kinase C; IP3, inositol 3-phosphate, Ca2+, calcium, PLA2, phspholipase A2; AA, arachidonic acid; COX, ciclooxigenase; PLC $\beta$, Phospholipase $\beta$.

function for platelet-derived APP in wound repair and in the microenvironmental regulation of the coagulation cascade. In fact, APP possesses growth factor activity [47], and recombinant soluble forms of APP were demonstrated to inhibit platelet aggregation and secretion induced by ADP or adrenaline, indicating that platelet degranulation may result in a negative feedback regulation of platelet activation [48].

\section{Atypical metabolism of amyloid precursor protein in coated-platelets}

Coated-platelets are a recently described subset of platelets that originate upon dual stimulation of platelets with collagen and thrombin which retain more full length APP on their surface than platelets activated with a single agonist $[49,50]$. Prodan and coworkers reported that there is an alteration of APP metabolism associated with the production of coated-platelets. Moreover, an altered production of coated-platelets in $\mathrm{AD}$ patients was also documented [51,52]. This finding is in line with earlier works of Davies and coworkers. However they observed an alteration of coated-platelets formation only in the most severely affected AD patients, while Prodan, observed an increased propensity to form coated-platelets in the mildly affected $\mathrm{AD}$ patients, that reverted during the progression of the disease [51-53]. In a more recent study was shown that elevated coated-platelet levels in patients with anamnestic MCI are associated with increased risk for progression to AD [54].

\section{Release of $A \beta$ peptides by circulating platelets}

The main species of $A \beta$ released from activated human platelets is $A \beta 1-40$. This is consistent with the observation that the circulating $A \beta$ forms contributing to vascular amyloid deposits are primary composed by $A \beta 1-40$, while the predominant form in neuronal plaques is $A \beta 1$ 42 [55-57]. Regarding the origin of $A \beta$ peptides in blood, two major theories have been proposed: Davies and coworkers [58] suggested that circulating $A \beta$ could derive from the central nervous system through the blood-CSF barrier, to become absorbed onto the surface blood cells, mostly platelets [51] and to a significantly lesser extend lymphocytes [18] and monocytes, which contain only about 5\% of the total APP in blood [59]. By contrast, others authors proposed that there is an additional release of $A \beta$ from blood cells and from other nonneuronal cells $[60,61]$. 
There is no doubt that $\mathrm{A} \beta$ peptides are actively released from platelets [62] and this process is significantly modulated by thrombin [63] and by PGE2 [64]. Smirnov and coworkers identified several forms of $A \beta$ peptide processed and secreted by stimulated and nonstimulated human platelets, including not only the classical A $\beta$ peptides $1-40,1-42$, but also several additional shorter, carboxyl-terminally truncated forms (A $\beta 1-39$, $\mathrm{A} \beta 1$-38, $A \beta 1-37, \mathrm{~A} \beta 1-34)$, an amino-terminally truncated form (A $\beta 2-42)$ and a further not identified form, arbitrarily termed $\mathrm{A} \beta 1-3 \mathrm{X}$, which is probably an oxidized form of $A \beta 1-40$ [62]. All these different forms appear to be released with different kinetics. These observations are in agreement with the findings that a highly conserved pattern of $A \beta$ peptides ( $A \beta 1-37, A \beta 1-38, A \beta 1-39$, $A \beta 1-40, A \beta 1-42$ ) was also described in cerebrospinal fluid $[65,66]$.

\section{Platelet activation by $A \beta$ peptides}

Synthetic peptides have been very useful to study the pathophysiological properties of $A \beta . A \beta 25-3$ is a synthetic peptide of 11 aminoacids located in the intermembrane domain of APP [21]. A $325-35$ cannot be produced through typical APP processing, but is often selected as an alternative model to full-length $A \beta$ because it retains both its physical and biological properties; it aggregates with time, forming fibrils with $\beta$-structure [67] and retains the toxicity of the full-length peptide $[68,69]$; moreover its short length readily allows derivatives to be synthesized and studied [70].

$\mathrm{A} \beta$ was able to activate platelets, and to trigger platelet aggregation by stimulating intracellular signaling pathways involving $\mathrm{PLC}_{2}$ phosphorylation, $\mathrm{PKC}$ activation and $\mathrm{Ca}^{2+}$ intracellular mobilization. Release of $\mathrm{A} \beta$ by activated platelets may represent a mechanism whereby $\mathrm{A} \beta$ deposition in the walls of blood vessels leads to angiopathy occuring in aging and $\mathrm{AD}[71,72]$.

In vitro experiments showed that low doses of $A \beta$ can potentiate agonist-induced platelet aggregation, and that higher doses are sufficient to directly trigger complete platelet aggregation [73]. These effects were similarly elicited by both A $325-35$ and A $\beta 1-40$ peptides, and have been linked to specifically signaling pathways [74]. The authors suggested a specific signaling pathway that initiates with the activation of the thrombin receptor PAR1 by $A \beta$ and leads to the subsequent subsequent Ras/Raf, PI3Kinase and Akt cascade activation. Subsequent activation of $\mathrm{p} 38 \mathrm{MAPK}$ leads to the stimulation of $\mathrm{CPLA}_{2}$, which catalyses the release of arachidonic acid for $\mathrm{TXA}_{2}$ synthesis [75]. TxA2 is then able to trigger activation of platelets and the consequent secretion of $A \beta$, raising the possibility that $A \beta$ activation of platelets may initiate a vicious cycle of platelet activation and $A \beta$ release, which may play a relevant role in the development of cerebral amyloid angiopathy [73].

More recent works established a structure-activity relationship between the polymerization state of $A \beta 1-40$ and its effects on platelet function: fibrillar $A \beta 1-40$ increases ADP stimulated 5-HT serotonin efflux [76]. In the presence of plasma $A \beta 1-40$ fibrils were unable to potentiate platelet aggregation. Perhaps the interactions between plasma lipoproteins and $A \beta$ peptides may represent a protective mechanism that reduces or blocks $A \beta$ toxicity [77]. It also been shown that $A \beta 1-40$ fibrils cause platelets activation supporting platelet adhesion and aggregation via a mechanism that may involve the expression of platelet fibrinogen receptors $[74,75]$.

\section{Platelets injury and $A \beta$ release}

Megakaryocytes are responsible for the production of platelets, by a massive cellular reorganization that leads to the formation of proplatelets. Proplatelets are extruded into the circulation where shear forces trigger their fragmentation, resulting in the release of platelets [76]. It is widely accepted that to produce platelets, megakaryocytes deliberately activate apoptosis [77-80]. Moreover, recent studies have suggested that circulating platelets themselves can undergo apoptosis [81-83].

Activation of apoptotic pathways in platelets can be also stimulated with the proapoptotic agent ionomicyn. This leads to a significant increase in intraplatelet $A \beta 40$, but not $A \beta 42$ [63], leading to the hypothesis that activation of apoptotic pathways in platelets determines an altered processing of APP. Caspases are centrally involved in apoptosis, and some reports indicate the presence of caspase family enzymes in platelets and their activation by extracellular agonists or during prolonged storage [84,85]. By western blot analysis, Casoli and coworkers detected inactive procaspase-3 in resting platelets. Interestingly, in ionomycin-treated platelets the proteolysed and active form of caspase-3 was detected [86], suggesting the initiation of apoptosis that eventually leads to overproduction of $A \beta 1-40$. Thus, $A \beta$ peptide production can be viewed as a consequence of a regular programmed cellular death.

\section{Do platelets play a role in inflammatory processes in AD?}

Besides having a key role in primary hemostasis, platelets play an important role in inflammatory processes. Among the most potent inflammatory signaling molecules secreted by platelets there are chemokines (such as platelet factor 4, PF4, RANTES, and MIP-1 $\alpha$, interleukins (IL-1 $\beta$, IL-7 and IL-8), prostaglandins and CD40L [87]. RANTES has been identified in platelets $\alpha$-granules, are released after activation and their secretion from PBMC is increased in AD [88]. MIP- $1 \alpha$ is a chemokine found in platelet $\alpha$-granules too. Its high levels in T-cells and brain microvessels of $\mathrm{AD}$ patients suggests that its 
upregulation could involve also platelets [89]. The platelet endothelial cell adhesion molecules, PECAM-1 and ICAM1 , were shown to be higher in plasma of $A D$ patients versus controls [90]. These proteins are present in platelets and participate in trans-endothelial migration of leukocytes when $A \beta$ peptide acts as an inflammatory stimulus [91,92].

The uncontrolled activation of platelets in $\mathrm{AD}$ patients can result in a chronic inflammatory reaction that can mediate endothelial cell stress. This, in turn, may determine further platelet activation creating a vicious circle that causes increased inflammation and release of $A \beta$. An alternative hypothesis is that the systemic inflammation present in AD determines platelet activation, stabilizing a process that proceeds in a self-amplifying way [89].

\section{Alteration of platelet sructure and function in ad}

It is now clear that platelet APP processing in AD patients is altered compared to normal control subjects, and may represent a useful peripheral bio-marker for the diagnosis of AD (Figure 2).

\section{Secretases activities}

In contrast to cells of neuronal origin, which predominantly process APP via the $\beta$-secretase pathway, platelets, like other non-neuronal cells, favor processing by $\alpha$-secretase. It is well established that sAPP $\alpha$ concentration in platelets is much higher than $A \beta$ peptides [40].

In fact in addition to cause degranulation and release of stored APP soluble fragments, platelet stimulation promotes primarily the proteolysis of intact APP expressed on the cell surface through $\alpha$-secretase activity. This process is supported by ADAM metalloproteinases, and causes the release of sAPP $\alpha$. In co-immunoprecipitation and pull-down experiments a physical association between the intracellular $\mathrm{Ca}^{2+}$ sensor calmodulin and APP was documented, revealing a key role of calmodulin in the regulation of non-amyloidogenic processing of APP [93].

In a previous study Smith and collaborators, observed that $\alpha$-secretase activity did not correlate with age, but it remained constant during the entire lifespan, while $\beta$-secretase activity in normal subjects significantly increased with age [94]. Ageing is recognized as being the principal risk factor for $\mathrm{AD}$ [95], and it is possible that the pathological changes occurring in $\mathrm{AD}$ may initiate very early in life. Moreover the increase of platelet $\beta$-secretase activity did not correlate with mini-mental state examination (MMSE) score, indicating that it did not occur as a secondary result

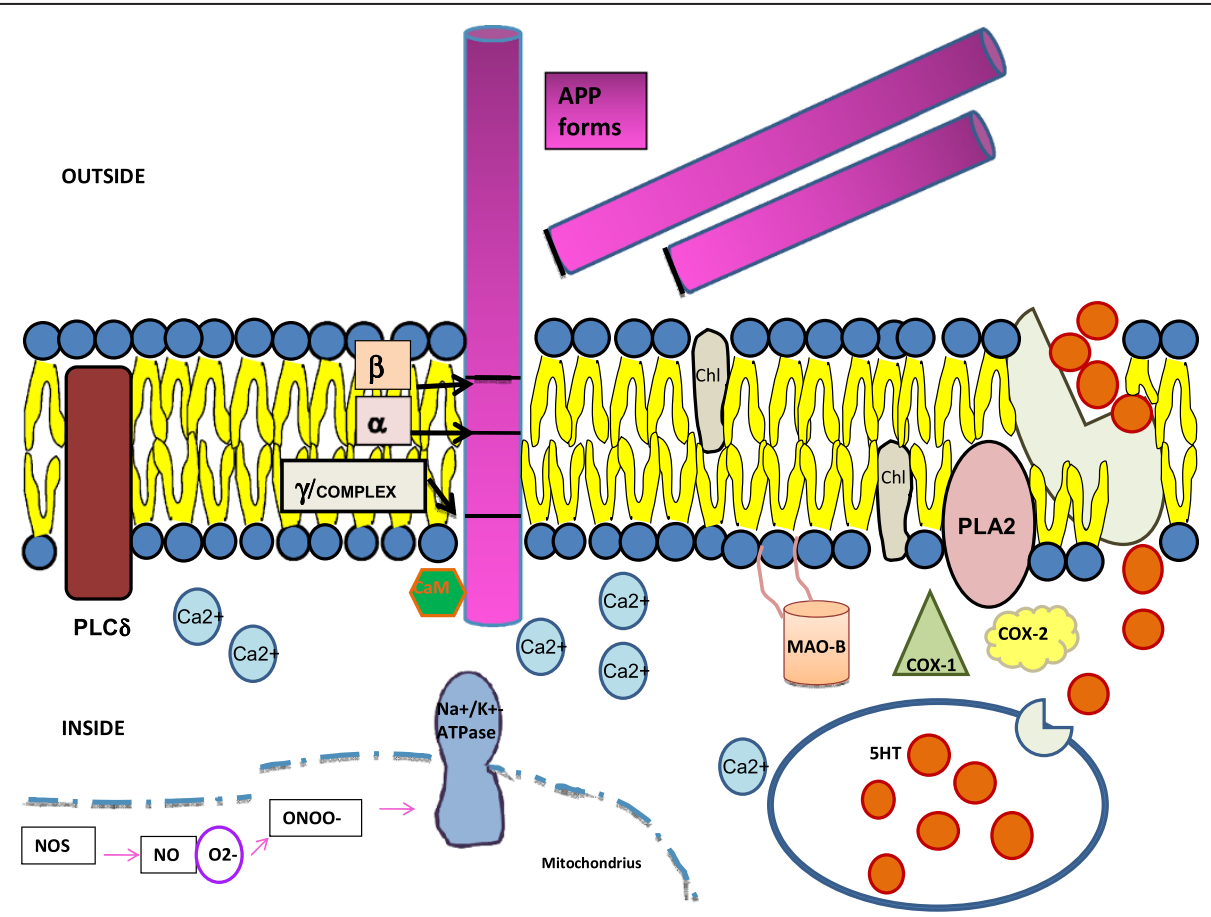

Figure 2 Abnormalities on AD platelets. Some membrane (secretases, phospholipases), cytosolic (monoamine oxidase, ciclooxigenases) and mithocondrial activities (nitric oxide synthase, sodium potassium ATPase pump) are compromised in AD platelets. Alterations are evident in the APP processing itself, membrane fluidity and cholesterol levels; in serotonin levels/uptake and intracellular $\mathrm{Ca}^{2+}$ levels; in nitric oxide and peroxynitrite production. Abbreviations: PLC $\delta$, phospholipase $C \delta ; \beta, \beta$-secretase; $a$, a-secretase; $\gamma$-secretase complex; APP forms, amyloid precursor protein forms; CaM, calmodulin; chl, cholesterol; MAO-B, monoamino-oxidase B; PLA2, phosholipase A2; COX-1, ciclooxigenase-1, COX-2, ciclooxigenase-2; 5HT, 5-hydroxytryptamine; NOS, nitric oxide synthase; NO nitric oxide; O2- superoxide anion; $\mathrm{ONOO}^{-}$peroxynitrite; $\mathrm{Na}+/ \mathrm{K}+-$ ATPase, sodium potassium ATPase pump; $\mathrm{Ca} 2+$, calcium. 
of the disease, and may even have preceded the onset of the symptoms [96]. These findings corroborate what already founded for the brains and cerebrospinal fluid of patients affected by $\mathrm{AD}$ [97-99]. Other authors reported that platelets from $\mathrm{AD}$ patients actually express increased BACE1 activity compared to controls [100,101]. In agreement with the increased $\beta$-secretase activity and decreased $\alpha$-secretase activity, the $A \beta$ levels have been found to be elevated in AD platelets samples [102]. At the present, there are no studies reporting alteration of the $\gamma$-secretase activity in $\mathrm{AD}$ patients.

\section{Membrane fluidity and cholesterol levels}

Some years ago an alteration of platelet membrane fluidity in AD was reported. This alteration had been ascribed to alteration of the internal membranes rather than to abnormal phospholipids synthesis [103-107].

A slight decrease in platelet membrane cholesterol level in a small group of AD patients was reported [108]. Recent evidence [109] proposed that increased membrane cholesterol results in increased $\beta$-secretase activity, that can generate more $A \beta 1-40$. As predicted by other studies [110], increased $A \beta 1-40$ may promote inhibition of HMG-CoA reductase, and reduce de-novo cholesterol biosynthesis. This model hypothesizes a negative feedback system between membrane $\beta$-secretase activity and membrane cholesterol level in AD. Therefore, it has been suggested that a perturbation of a possible physiological homeostatic link between membrane cholesterol level and membrane $\beta$-secretase activity may occur in AD. Treatment with statin may restore this link [109].

\section{Phospholipases}

A key enzyme in platelets signal transduction is the phosphoinositide-specific phospholipase C, PLC. Its involvement in $\mathrm{AD}$ dates back some years ago when Shimohama and coworker demonstrated that the PLC $\delta$ - 1 isoform abnormally accumulates in the brain in AD [111]. Subsequently it was demonstrated that PLC activity was significantly lower in the AD platelets than in controls, suggesting an aberrant phosphoinositides metabolism in non-neuronal tissues [112]. Moreover the activity of PLC $\delta 1$ isozyme is reduced in $\mathrm{AD}$ patient homozygous for apoE genotype carrying the $\varepsilon 3$ allele, but was normal in patients with the $\varepsilon 4$ allele [113].

Phospholipase $\mathrm{A}_{2}, \mathrm{PLA}_{2}$, plays an essential role in the metabolism of membrane phospholipids [114], but its activation can also stimulates the secretion of APP [115], and, on the other hand amyloid peptides are able to activate $\mathrm{PLA}_{2}$ in vitro [116]. $\mathrm{PLA}_{2}$ activity was found to be increased in platelets from individuals with $\mathrm{AD}$ [117]. These data conflict with those of other studies in which $\mathrm{PLA}_{2}$ activity in human platelets [118] as well as in human brain AD $[119,120]$ was found to be decreased in AD samples.

\section{Serotonin levels and uptake}

Several studies have reported abnormalities in the cellular content of serotonin in $\mathrm{AD}$, as well as alterations of its uptake in different regions of the brains of $\mathrm{AD}$ patients [121,122]. Studies performed on AD platelets reported confused results concerning the uptake of serotonin. While some works failed to detect any alteration in the level of serotonin in $\mathrm{AD}$ patients compared to controls [123], others documented a reduced uptake of serotonin into AD platelets [124,125].

In accord to the diminished platelet serotonin concentration and increased plasma serotonin levels in patients with AD, Sevush and coworkers, observed that unstimulated platelets of AD patients exhibit greater activation of than those of controls [126]. A recent work shows a persistently enhancement of platelets activation of $\mathrm{AD}$ patients, which may be related, on increased lipid peroxidation associated with inadequate levels of Vitamin E [127].

A straight correlation between the uptake of 5-hydroxytryptamine, 5- $\mathrm{HT}$ and cognitive state of the AD patients was also reported. A significantly lower concentrations of serotonin in platelets from $\mathrm{AD}$ patients was peculiar of those subjects in the late phase of $\mathrm{AD}$. Hence, the decreased platelet serotonin concentration observed in the late phase of $\mathrm{AD}$ might be related to a reduced serotonin uptake [128].

\section{Monoamine oxidase activity}

Few studies performed on platelet MAO-B activity in $\mathrm{AD}$ yielded inconsistent but intresting results: Adolfsson and coworkers report increased MAO-B activity in platelets and brain of $\mathrm{AD}$ [129], while Ahlskog did not find any alteration of MAO-B activity in AD versus controls [130]. More recent studies indicated that MAO-B activity might be used as a biomarker for the presence of psychotic features in AD [131], and for the early or late onset $\mathrm{AD}$ [132]. In the above cited work by Muck-Seler and coworkers, the MAO-B activity was in line with serotonin concentration: significantly lower in patients in the late phase of $\mathrm{AD}$ compared to other phases of $\mathrm{AD}$ or healthy controls. Authors have found a positive correlation between MMSE scores and platelet MAO-B activity in $\mathrm{AD}$, thus indicating that more severe $\mathrm{AD}$ symptoms are associated to lower MAO-B activity [128].

\section{Cyclooxygenase}

Current data suggest that protein kinase $\mathrm{C}$, along with PI3K activity and $\mathrm{Ca}^{2+}$, is crucially involved in APP cleavage and secretion in human platelets, while COX is a minor component of APP secretion pathway. By contrast, 
$\mathrm{A} \beta$ release is totally independent of both PKC and COX activity, meanwhile $\mathrm{Ca}^{2+}$ plays an important role also in the release of $A \beta$ [54].

Other evidence linked to the action of COX enzymes in brains, suggest a determinant role of COX as inflammatory marker in peripheral cells of $\mathrm{AD}$, as platelets.

Activated platelets express almost exclusively, COX-1. COX-2 isozyme is normally undetectable in most tissue, but can be rapidly induced by proinflammatory or mitogenic stimuli. Elevated concentrations of circulating cytokines could upregulate COX-2 in megakaryocytes with a subsequent increase of it content in platelets. Bermejo and coworkers, reported an increased platelets levels of COX2 in $\mathrm{AD}$ and $\mathrm{MCI}$ patients compared to elderly controls, indicating that platelet inflammatory pathways are activated, and that this could be considered an early event in AD development [133].

\section{Nitric oxide synthase and free radicals generation}

Oxidative stress has been widely implicated both in ageing and in pathogenesis of several neurodegenerative disorders, including AD. Some studies showed an increase of nitric oxide, $\mathrm{NO}$ and peroxynitrite anion, $\mathrm{ONOO}^{-}$, production exclusively in platelets obtained from $\mathrm{AD}$ patients, that was associated to a decreased $\mathrm{Na}^{+} / \mathrm{K}^{+}$-ATPase activity in $\mathrm{AD}$ patients platelet membrane [134]. In a vertical study, nitric oxide syntase, NOS, activity, was measured in platelets of young controls, aged controls and $\mathrm{AD}$ patients, and a significant increase was seen when $\mathrm{AD}$ were compared with aged controls and, more significant, when compared with young controls [135]. In a study performed on mild and moderate $\mathrm{AD}$ patients, platelet aggregation was found to be potentiated, and this was paralleled by a decline of endothelial, constitutive NOS activity, causing a reduction of the NO concentration in platelets. This reduction was proposed to be responsible for the increased aggregation in $\mathrm{AD}$ patients, since $\mathrm{NO}$ can inhibit platelet aggregation [136]. This model, however, is in contrast with the well documented notion that NO concentration and NOS activity is higher in $\mathrm{AD}$ than controls. Therefore, additional works are necessary to determine the role of $\mathrm{NO}$ system in AD platelets.

\section{Alteration of APP processing}

The alteration of APP processing in platelets from AD patients was investigated at least by three different groups, who measured the ratio between the different types (or isoforms) of APP detectable in platelets on the basis of a different apparent molecular mass on SDS-PAGE.

Rosenberg and coworkers determined the ratio of the 120-130 KDa APP isoform to the $110 \mathrm{KDa}$ APP isoform, and showed that APP processing in AD platelets is compromised compared to that of control subjects $[101,137,138]$. The authors propose that this difference may reflect chronic platelet activation in patients with $\mathrm{AD}$. They also determined a direct correlation between the cognitive decline by MMSE scores in AD patients during three years of follow-up and APP isoform ratio reduction.

Liu and coworkers revealed that AD patients whose MMSE scores declined in one year, had a greater reduction in platelet APP isoforms ratio than patients whose MMSE scores did not decline [139].

An altered ratio among the different APP isoforms detectable in platelets from $\mathrm{AD}$ patients was confirmed by many other studies $[59,140,141]$, as it was the demonstration of a positive correlation between APP ratios and the progression of clinical symptoms, suggesting that this peripheral parameter may be a marker of progression of the disease.

Subsequently studies reported that platelets of patients carrying the mutation Met293Val in PS2 protein did not show altered expression of APP isoforms ratio pattern conversely to what reported for sporadic $\mathrm{AD}$ patients [142].

It was demonstrated an association between early stages of $\mathrm{AD}$, or of Mild Cognitive Impairment, $\mathrm{MCI}$, with a reduction in platelet APP isoforms ratio, and suggested that, since alteration of APP processing may be an early event in $\mathrm{AD}$, the characterization of APP ratio in platelet could have a great diagnostic power [8,143-145]. In conclusion, platelet APP isoforms ratio may be a very important $\mathrm{AD}$ biomarker, as its evaluation is reliable and simple test to be performed.

\section{Conclusion}

Initially identified as an exclusively brain tissue disorder, in the last decades, AD, was revaluated as a more intriguing disorder involving many other peripheral tissues and molecules in the organism. In fact, it is now well established that biochemical alterations in AD patients do not occur only in the brain, but even in blood vessels and blood cells. Nowday researchers have recognized that platelets are the principal components of human blood to be affected not only in the onset but even in the progression of $\mathrm{AD}$. Platelets seem to mirror what happens in nervous tissue during the evolution of $\mathrm{AD}$, and therefore represent the cellular type where to identified the early events in the onset of the disorder. Differently from neurons, platelets can be easily accessible and constitute a valid cellular tool to study the pathogenesis of AD. In this review we have summarized the limited and often discordant results reported by different authors in recent years. Overall all these studies, both in vivo and in vitro, are aimed to understand in which way affected proteins, enzymes, signal transduction pathways, inflammatory processes, spontaneous activation are important in platelets to better define the molecular pathogenesis of $\mathrm{AD}$. Platelets are primary the principal authors of hemostasis in the organism, but they also play 
a key role in Alzheimer Disease still remaining a potential marker to understand the diagnosis of the disorder.

\section{Competing interests}

The authors declare that they have no competing interests.

\section{Authors' contributions}

SC wrote the manuscript. MT and GR edited the manuscript. All authors read and approved the final manuscript.

\section{Author details}

'Department of Molecular Medicine, Haematology Section, Fondazione IRCCS Policlinico San Matteo, Pavia, Italy. ${ }^{2}$ Department of Biochemistry, University of Pavia, Via Bassi 21, Pavia, Italy. ${ }^{3}$ Department of Internal Medicine and Therapeutics, Section of Geriatrics, University of Pavia, ASP-IDR S. Margherita, Via Emilia 12, Pavia 27100, Italy.

Received: 24 May 2012 Accepted: 1 August 2012

Published: 17 September 2012

\section{References}

1. Yankner BA, Mesulam MM: Beta-Amyloid and the pathogenesis of Alzheimer's disease. Seminars in medicine of the Beth Israel Hospital, Boston. New England Journal Medical 1991, 325(26):1849-1857. Review.

2. Selkoe DJ: The molecular pathology of Alzheimer's disease. Neuron 1991, 6(4):487-498. Review.

3. Hampel H, Frank R, Broich K, Teipel SJ, Katz RG, Hardy J, Herholz K, Bokde AL, Jessen F, Hoessler YC, Sanhai WR, Zetterberg H, Woodcock J, Blennow K: Biomarkers for Alzheimer's disease: academic, industry and regulatory perspectives. Nat Rev Drug Discov 2010, 9(7):560-574. Review.

4. Alzheimer A: Uber eine eigenartige Erkrankung der Hirnrinde. Allg Zeitschr Psychiatr 1907, 64:146-148.

5. Maccioni RB, Muñoz JP, Barbeito L: The molecular bases of Alzheimer's disease and other neurodegenerative disorders. Arch Med Res 2001, 32(5):367-381. Review.

6. Fraser SP, Suh YH, Djamgoz MB: lonic effects of the Alzheimer's disease beta-amyloid precursor protein and its metabolic fragments. Trends Neurosci 1997, 20(2):67-72. Review.

7. Walsh DM, Selkoe DJ: A beta oligomers-a decade of discovery. $J$ Neurochem 2007, 101(5):1172-1184. Review.

8. Hampel H, Shen Y, Walsh DM, Aisen P, Shaw LM, Zetterberg H, Trojanowsk $\mathrm{JQ}$, Blennow K: Biological markers of amyloid beta-related mechanisms in Alzheimer's disease. Exp Neurol 2010, 223(2):334-346.

9. Borroni B, Colciaghi F, Corsini P, Akkawi N, Rozzini L, Del Zotto E, Talarico G, Cattabeni F, Lenzi GL, Di Luca M, Padovani A: Early stages of probable Alzheimer disease are associated with changes in platelet amyloid precursor protein forms. Neurol Sci 2002, 23(5):207-210.

10. Bird TD: Genetic factors in Alzheimer's disease. N Engl J Med 2005, 352(9):862-864.

11. Turner RS: Alzheimer's disease. Semin Neurol 2006, 26(5):499-506.

12. Corder EH, Saunders AM, Strittmatter WJ, Schmechel DE, Gaskell PC, Small GW, Roses AD, Haines JL, Pericak-Vance MA: Gene dose of apolipoprotein E type 4 allele and the risk of Alzheimer's disease in late onset families. Science 1993, 261(5123):921-923.

13. Strittmatter WJ, Weisgraber KH, Huang DY, Dong LM, Salvesen GS, PericakVance M, Schmechel D, Saunders AM, Goldgaber D, Roses AD: Binding of human apolipoprotein $E$ to synthetic amyloid beta peptide: isoformspecific effects and implications for late-onset Alzheimer disease. Proc Natl Acad Sci U S A 1993, 90(17):8098-8102.

14. Weidemann A, König G, Bunke D, Fischer P, Salbaum JM, Masters CL, Beyreuther K: Identification, biogenesis, and localization of precursors of Alzheimer's disease A4 amyloid protein. Cell 1989, 57(1):115-126.

15. Selkoe DJ, Podlisny MB, Joachim CL, Vickers EA, Lee G, Fritz LC, Oltersdorf T: Beta-amyloid precursor protein of Alzheimer disease occurs as 110- to 135-kilodalton membrane-associated proteins in neural and nonneural tissues. Proc Natl Acad Sci U S A 1988, 85(19):7341-7345.

16. Bush Al, Martins RN, Rumble B, Moir R, Fuller S, Milward E, Currie J, Ames D, Weidemann A, Fischer P, Multhaup G, Beyreuther K, Masters CL: The amyloid precursor protein of Alzheimer's disease is released by human platelets. J Biol Chem 1990, 265(26):15977-15983.
17. Tanzi RE, McClatchey Al, Lamperti ED, Villa-Komaroff L, Gusella JF, Neve RL: Protease inhibitor domain encoded by an amyloid protein precursor mRNA associated with Alzheimer's disease. Nature 1988, 331(6156): 528-530.

18. Li QX, Fuller SJ, Beyreuther K, Masters CL: The amyloid precursor protein of Alzheimer disease in human brain and blood. J Leukoc Biol 1999, 66(4):567-574. Review.

19. Golde TE, Estus S, Usiak M, Younkin LH, Younkin SG: Expression of beta amyloid protein precursor mRNAs: recognition of a novel alternatively spliced form and quantitation in Alzheimer's disease using PCR. Neuron 1990, 4(2):253-267.

20. Li QX, Berndt MC, Bush Al, Rumble B, Mackenzie I, Friedhuber A, Beyreuther K, Masters CL: Membrane-associated forms of the beta A4 amyloid protein precursor of Alzheimer's disease in human platelet and brain: surface expression on the activated human platelet. Blood 1994, 84(1):133-142

21. Kang J, Lemaire HG, Unterbeck A, Salbaum JM, Masters CL, Grzeschik KH, Multhaup G, Beyreuther K, Müller-Hill B: The precursor of Alzheimer's disease amyloid A4 protein resembles a cell-surface receptor. Nature 1987, 325(6106):733-736.

22. Evin G, Weidemann A: Biogenesis and metabolism of Alzheimer's disease Abeta amyloid peptides. Peptides 2002, 23(7):1285-1297.

23. Gralle M, Ferreira ST: Structure and functions of the human amyloid precursor protein: the whole is more than the sum of its parts. Prog Neurobiol 2007, 82(1):11-32.

24. Golde TE, Cai XD, Shoji M, Younkin SG: Production of amyloid beta protein from normal amyloid beta-protein precursor (beta APP) and the mutated beta APPS linked to familial Alzheimer's disease. Ann N Y Acad Sci 1993, 695:103-108. Review.

25. Gralle M, Botelho MG, Wouters FS: Neuroprotective secreted amyloid precursor protein acts by disrupting amyloid precursor protein dimers. J Biol Chem 2009, 284(22):15016-15025.

26. Racchi M, Govoni S: The pharmacology of amyloid precursor protein processing. Exp Gerontol 2003, 38(1-2):145-157. Review.

27. Kroll MH, Schafer Al: Biochemical mechanisms of platelet activation. Blood 1989, 74(4):1181-1195.

28. Cupello A, Favale E, Audenino D, Scarrone S, Gastaldi S, Albano C: Decrease of serotonin transporters in blood platelets after epileptic seizures. Neurochem Res 2005, 30(4):425-428.

29. Rainesalo S, Keränen T, Saransaari P, Honkaniemi J: GABA and glutamate transporters are expressed in human platelets. Brain Res Mol Brain Res 2005, 141(2):161-165.

30. Götz J, Ittner LM: Animal models of Alzheimer's disease and frontotemporal dementia. Nat Rev Neurosci 2008, 9(7):532-544. Review.

31. D'Amelio M, Cavallucci V, Middei S, Marchetti C, Pacioni S, Ferri A, Diamantini A, De Zio D, Carrara P, Battistini L, Moreno S, Bacci A Ammassari-Teule M, Marie H, Cecconi F: Caspase-3 triggers early synaptic dysfunction in a mouse model of Alzheimer's disease. Nat Neurosci 2011 14(1):69-76.

32. Jacobsen JS, Wu CC, Redwine JM, Comery TA, Arias R, Bowlby M, Martone R, Morrison JH, Pangalos MN, Reinhart PH, Bloom FE: Early-onset behavioral and synaptic deficits in a mouse model of Alzheimer's disease. Proc Natl Acad Sci U S A 2006, 103(13):5161-5166.

33. Cruz JC, Kim D, Moy LY, Dobbin MM, Sun X, Bronson RT, Tsai LH: p25/ cyclin-dependent kinase 5 induces production and intraneuronal accumulation of amyloid beta in vivo. J Neurosci 2006, 26(41): 10536-10541.

34. Qin RA, Yao XX, Huang ZY: Effects of compound danshen tablets on spatial cognition and expression of brain beta-amyloid precursor protein in a rat model of Alzheimer's disease. J Tradit Chin Med 2012, 32(1):63-66.

35. Li QX, Evin G, Small DH, Multhaup G, Beyreuther K, Masters CL: Proteolytic processing of Alzheimer's disease beta A4 amyloid precursor protein in human platelets. J Biol Chem 1995, 270(23):14140-14147.

36. Chen $M$, Inestrosa NC, Ross GS, Fernandez HL: Platelets are the primary source of amyloid beta-peptide in human blood. Biochem Biophys Res Commun 1995, 213(1):96-103.

37. Deane R, Zlokovic BV: Role of the blood-brain barrier in the pathogenesis of Alzheimer's disease. Curr Alzheimer Res 2007, 4(2):191-197. Review.

38. Roher AE, Esh CL, Kokjohn TA, Castaño EM, Van Vickle GD, Kalback WM, Patton RL, Luehrs DC, Daugs ID, Kuo YM, Emmerling MR, Soares H, Quinn JF, Kaye J, Connor DJ, Silverberg NB, Adler CH, Seward JD, Beach TG, 
Sabbagh MN: Amyloid beta peptides in human plasma and tissues and their significance for Alzheimer's disease. Alzheimers Dement 2009, 5(1):18-29.

39. Gardella JE, Ghiso J, Gorgone GA, Marratta D, Kaplan AP, Frangione B, Gorevic PD: Intact Alzheimer amyloid precursor protein (APP) is present in platelet membranes and is encoded by platelet mRNA. Biochem Biophys Res Commun 1990, 173(3):1292-1298.

40. Li QX, Whyte S, Tanner JE, Evin G, Beyreuther K, Masters CL: Secretion of Alzheimer's disease Abeta amyloid peptide by activated human platelets. Lab Invest 1998, 78(4):461-469.

41. Smith CCT: Stimulated release of the b-amyloid protein of Alzheimer's disease by normal human platelets. Neurosc Lett 1997, 235:157-159.

42. Evin G, Zhu A, Holsinger RM, Masters CL, Li QX: Proteolytic processing of the Alzheimer's disease amyloid precursor protein in brain and platelets. J Neurosci Res 2003, 74(3):386-392.

43. Kitaguchi N, Takahashi Y, Tokushima Y, Shiojiri S, Ito H: Novel precursor of Alzheimer's disease amyloid protein shows protease inhibitory activity. Nature 1988, 331(6156):530-532.

44. Mattson MP: Calcium and neuronal injury in Alzheimer's disease. Contributions of beta-amyloid precursor protein mismetabolism, free radicals, and metabolic compromise. Ann N Y Acad Sci 1994, 747:50-76. Review.

45. Van Nostrand WE, Schmaier AH, Wagner SL: Potential role of protease nexin-2/amyloid beta-protein precursor as a cerebral anticoagulant. Ann N Y Acad Sci 1992, 674:243-252. Review.

46. Mahdi F, Van Nostrand WE, Schmaier AH: Protease nexin-2/amyloid betaprotein precursor inhibits factor $\mathrm{Xa}$ in the prothrombinase complex. J Biol Chem 1995, 270(40):23468-23474.

47. Milward EA, Papadopoulos R, Fuller SJ, Moir RD, Small D, Beyreuther K, Masters CL: The amyloid protein precursor of Alzheimer's disease is a mediator of the effects of nerve growth factor on neurite outgrowth. Neuron 1992, 9(1):129-137.

48. Henry A, Li QX, Galatis D, Hesse L, Multhaup G, Beyreuther K, Masters CL, Cappai R: Inhibition of platelet activation by the Alzheimer's disease amyloid precursor protein. Br J Haematol 1998, 103(2):402-415.

49. Alberio L, Safa O, Clemetson KJ, Esmon CT, Dale GL: Surface expression and functional characterization of alpha-granule factor $\mathrm{V}$ in human platelets: effects of ionophore A23187, thrombin, collagen, and convulxin. Blood 2000, 95(5):1694-1702.

50. Dale GL: Coated-platelets: an emerging component of the procoagulant response. J Thromb Haemost 2005, 3(10):2185-2192. Review.

51. Prodan Cl, Szasz R, Vincent AS, Ross ED, Dale GL: Coated-platelets retain amyloid precursor protein on their surface. Platelets 2006, 17(1):56-60.

52. Prodan Cl, Ross ED, Vincent AS, Dale GL: Coated-platelets correlate with disease progression in Alzheimer disease. J Neurol 2007, 254(4):548-549.

53. Davies TA, Long HJ, Sgro K, Rathbun WH, McMenamin ME, Seetoo K, Tibbles $\mathrm{H}$, Billingslea AM, Fine RE, Fishman JB, Levesque CA, Smith SJ, Wells JM, Simons ER: Activated Alzheimer disease platelets retain more beta amyloid precursor protein. Neurobiol Aging 1997, 18(2):147-153.

54. Prodan Cl, Ross ED, Stoner JA, Cowan LD, Vincent AS, Dale GL: Coatedplatelet levels and progression from mild cognitive impairment to Alzheimer disease. Neurology 2011, 76:247-252.

55. Skovronsky DM, Lee VM, Praticò D: Amyloid precursor protein and amyloid beta peptide in human platelets. Role of cyclooxygenase and protein kinase C. J Biol Chem 2001, 276(20):17036-17043.

56. Herzig MC, Winkler DT, Burgermeister P, Pfeifer M, Kohler E, Schmidt SD, Danner S, Abramowski D, Stürchler-Pierrat C, Bürki K, van Duinen SG, MaatSchieman ML, Staufenbiel M, Mathews PM, Jucker M: Abeta is targeted to the vasculature in a mouse model of hereditary cerebral hemorrhage with amyloidosis. Nat Neurosci 2004, 7(9):954-960

57. Fryer JD, Holtzman DM: The bad seed in Alzheimer's disease. Neuron 2005 47(2):167-168

58. Davies TA, Long HJ, Eisenhauer PB, Hastey R, Cribbs DH, Fine RE, Simons ER: Beta amyloid fragments derived from activated platelets deposit in cerebrovascular endothelium: usage of a novel blood brain barrier endothelial cell model system. Amyloid 2000, 7(3):153-165.

59. Giri R, Selvaraj S, Miller CA, Hofman F, Yan SD, Stern D, Zlokovic BV, Kalra VK: Effect of endothelial cell polarity on beta-amyloid-induced migration of monocytes across normal and AD endothelium. Am J Physiol Cell Physiol 2002, 283(3):C895-C904.
60. Di Luca M, Colciaghi F, Pastorino L, Borroni B, Padovani A, Cattabeni F: Platelets as a peripheral district where to study pathogenetic mechanisms of alzheimer disease: the case of amyloid precursor protein. Eur J Pharmacol 2000, 405(1-3):277-283. Review.

61. Pluta R: Blood-brain barrier dysfunction and amyloid precursor protein accumulation in microvascular compartment following ischemiareperfusion brain injury with 1-year survival. Acta Neurochir Supp/ 2003, 86:117-122.

62. Smirnov A, Trupp A, Henkel AW, Bloch E, Reulbach U, Lewczuk P, Riggert J, Kornhuber J, Wiltfang J: Differential processing and secretion of Abeta peptides and SAPPalpha in human platelets is regulated by thrombin and prostaglandine 2. Neurobiol Aging 2009, 30(10):1552-1562.

63. Casoli T, Di Stefano G, Giorgetti B, Grossi Y, Balietti M, Fattoretti P, BertoniFreddari $C$ : Release of beta-amyloid from high-density platelets: implications for Alzheimer's disease pathology. Ann N Y Acad Sci 2007, 1096:170-178

64. Gray SJ, Heptinstall S: The effects of PGE2 and CL 115,347, an antihypertensive PGE2 analogue, on human blood platelet behaviour and vascular contractility. Eur J Pharmacol 1985, 114(2):129-137.

65. Wiltfang J, Smirnov A, Schnierstein B, Kelemen G, Matthies U, Klafki HW, Staufenbiel M, Hüther G, Rüther E, Kornhuber J: Improved electrophoretic separation and immunoblotting of beta-amyloid ( $A$ beta) peptides 1-40, 1-42, and 1-43. Electrophoresis 1997, 18(3-4):527-532.

66. Wiltfang J, Esselmann H, Smirnov A, Bibl M, Cepek L, Steinacker P, Mollenhauer B, Buerger K, Hampel H, Paul S, Neumann M, Maler M, Zerr I, Kornhuber J, Kretzschmar HA, Poser S, Otto M: Beta-amyloid peptides in cerebrospinal fluid of patients with Creutzfeldt-Jakob disease. Ann Neurol 2003, 54(2):263-267.

67. Del Mar Martínez-Senac M, Villalaín J, Gómez-Fernández JC: Structure of the Alzheimer beta-amyloid peptide (25-35) and its interaction with negatively charged phospholipid vesicles. Eur J Biochem 1999, 265(2):744-753.

68. Iversen LL, Mortishire-Smith RJ, Pollack SJ, Shearman MS: The toxicity in vitro of beta-amyloid protein. Biochem J 1995, 311(Pt 1):1-16. Review.

69. Terzi E, Hölzemann G, Seelig J: Alzheimer beta-amyloid peptide 25-35: electrostatic interactions with phospholipid membranes. Biochemistry 1994, 33(23):7434-7441.

70. Hughes E, Burke RM, Doig AJ: Inhibition of toxicity in the beta-amyloid peptide fragment beta -(25-35) using $\mathrm{N}$-methylated derivatives: a general strategy to prevent amyloid formation. J Biol Chem 2000, 275 (33):25109-25115.

71. Shen MY, Hsiao G, Fong TH, Chou DS, Sheu JR: Expression of amyloid beta peptide in human platelets: pivotal role of the phospholipase Cgamma2-protein kinase $C$ pathway in platelet activation. Pharmacol Res 2008, 57(2):151-158.

72. Thomas T, Thomas G, McLendon C, Sutton T, Mullan M: eta-Amyloidmediated vasoactivity and vascular endothelial damage. Nature 1996, 380(6570):168-171.

73. Shen MY, Hsiao G, Fong TH, Chen HM, Chou DS, Lin CH, Sheu JR, Hsu CY: Amyloid beta peptide-activated signal pathways in human platelets. Eur J Pharmacol 2008, 588(2-3):259-266.

74. Bugaud F, Nadal-Wollbold F, Lévy-Toledano S, Rosa JP, Bryckaert M: Regulation of c-jun-NH2 terminal kinase and extracellular-signal regulated kinase in human platelets. Blood 1999, 94(11):3800-3805.

75. Coulon L, Calzada C, Moulin P, Véricel E, Lagarde M: Activation of p38 mitogen-activated protein kinase/cytosolic phospholipase A2 cascade in hydroperoxide-stressed platelets. Free Radic Biol Med 2003, 35(6):616-625.

76. Italiano JE Jr, Lecine P, Shivdasani RA, Hartwig JH: Blood platelets are assembled principally at the ends of proplatelet processes produced by differentiated megakaryocytes. J Cell Biol 1999, 147(6):1299-1312.

77. Kaluzhny Y, Ravid K: Role of apoptotic processes in platelet biogenesis. Acta Haematol 2004, 111(1-2):67-77.

78. Fadeel B, Orrenius S: Apoptosis: a basic biological phenomenon with wide-ranging implications in human disea. J Intern Med 2005, 258(6):479-517. Review.

79. Patel SR, Hartwig JH, Italiano JE Jr: The biogenesis of platelets from megakaryocyte proplatelets. J Clin Invest 2005, 115(12):3348-3354. Review.

80. Josefsson EC, James C, Henley KJ, Debrincat MA, Rogers KL, Dowling MR, White MJ, Kruse EA, Lane RM, Ellis S, Nurden P, Mason KD, O'Reilly LA, Roberts AW, Metcalf D, Huang DC, Kile BT: Megakaryocytes possess a functional intrinsic apoptosis pathway that must be restrained to survive and produce platelets. J Exp Med 2011, 208(10):2017-2031. 
81. Brown SB, Clarke MC, Magowan L, Sanderson H, Savill J: Constitutive death of platelets leading to scavenger receptor-mediated phagocytosis. A caspase-independent cell clearance program. J Biol Chem 2000, 275(8):5987-5996.

82. Pereira J, Soto M, Palomo I, Ocqueteau M, Coetzee LM, Astudillo S, Aranda E, Mezzano D: Platelet aging in vivo is associated with activation of apoptotic pathways: studies in a model of suppressed thrombopoiesis in dogs. Thromb Haemost 2002, 87(5):905-909.

83. Rand ML, Wang H, Bang KW, Poon KS, Packham MA, Freedman J: Procoagulant surface exposure and apoptosis in rabbit platelets: association with shortened survival and steady-state senescence. J Thromb Haemost 2004, 2(4):651-659.

84. Shcherbina A, Remold-O'Donnell E: Role of caspase in a subset of human platelet activation responses. Blood 1999, 93(12):4222-4231.

85. Plenchette S, Moutet M, Benguella M, N'Gondara JP, Guigner F, Coffe C, Corcos L, Bettaieb A, Solary E: Early increase in DcR2 expression and late activation of caspases in the platelet storage lesion. Leukemia 2001, 15(10):1572-1581.

86. Wolf BB, Goldstein JC, Stennicke HR, Beere H, Amarante-Mendes GP, Salvesen GS, Green DR: Calpain functions in a caspase-independent manner to promote apoptosis-like events during platelet activation. Blood 1999, 94(5):1683-1692.

87. Klinger MH: Platelets and inflammation. Anat Embryol (Berl) 1997, 196(1):1-11. Review.

88. Iarlori C, Gambi D, Gambi F, Lucci I, Feliciani C, Salvatore M, Reale M: Expression and production of two selected beta-chemokines in peripheral blood mononuclear cells from patients with Alzheimer's disease. Exp Gerontol 2005, 40(7):605-611.

89. Casoli T, Di Stefano G, Balietti M, Solazzi M, Giorgetti B, Fattoretti P. Peripheral inflammatory biomarkers of Alzheimer's disease: the role of platelets. Biogerontology 2010, 11(5):627-633. Review.

90. Nielsen HM, Londos E, Minthon L, Janciauskiene SM: Soluble adhesion molecules and angiotensin-converting enzyme in dementia. Neurobiol Dis 2007, 26(1):27-35

91. Giri R, Shen Y, Stins M, Du Yan S, Schmidt AM, Stern D, Kim KS, Zlokovic B, Kalra VK: Beta-amyloid-induced migration of monocytes across human brain endothelial cells involves RAGE and PECAM-1. Am J Physiol Cell Physiol 2000, 279(6):C1772-C1781.

92. Suo Z, Tan J, Placzek A, Crawford F, Fang C, Mullan M: Alzheimer's betaamyloid peptides induce inflammatory cascade in human vascular cells: the roles of cytokines and CD40. Brain Res 1998, 807(1-2):110-117.

93. Canobbio I, Catricalà S, Balduini C, Torti M: Calmodulin regulates the nonamyloidogenic metabolism of amyloid precursor protein in platelets. Biochim Biophys Acta 2011, 1813(3):500-506.

94. Smith CC, Prichard BN, Cooper MB: Platelet alpha- and beta-secretase activities: A preliminary study in normal human subjects. Platelets 2009, 20(1):29-34.

95. Carr DB, Goate A, Phil D, Morris JC: Current concepts in the pathogenesis of Alzheimer's disease. Am J Med 1997, 103(3A):3S-10S. Review.

96. Johnston JA, Liu WW, Coulson DT, Todd S, Murphy S, Brennan S, Foy CJ, Craig D, Irvine GB, Passmore AP: Platelet beta-secretase activity is increased in Alzheimer's disease. Neurobiol Aging 2008, 29(5):661-668

97. Fukumoto $H$, Cheung BS, Hyman BT, Irizarry MC: Beta-secretase protein and activity are increased in the neocortex in Alzheimer disease. Arch Neurol 2002, 59(9):1381-1389.

98. Li R, Lindholm K, Yang LB, Yue X, Citron M, Yan R, Beach T, Sue L, Sabbagh $M$, Cai H, Wong P, Price D, Shen Y: Amyloid beta peptide load is correlated with increased beta-secretase activity in sporadic Alzheimer's disease patients. Proc Natl Acad Sci U S A 2004, 101(10):3632-3637.

99. Holsinger RM, McLean CA, Collins SJ, Masters CL, Evin G: Increased betaSecretase activity in cerebrospinal fluid of Alzheimer's disease subjects. Ann Neurol 2004, 55(6):898-899.

100. Colciaghi F, Borroni B, Pastorino L, Marcello E, Zimmermann M, Cattabeni F, Padovani A, Di Luca M: [alpha]-Secretase ADAM10 as well as [alpha]APPs is reduced in platelets and CSF of Alzheimer disease patients. Mol Med 2002, 8(2):67-74

101. Colciaghi F, Marcello E, Borroni B, Zimmermann M, Caltagirone C, Cattabeni F, Padovani A, Di Luca M, Platelet APP: ADAM 10 and BACE alterations in the early stages of Alzheimer disease. Neurology 2004, 62(3):498-501.
102. Tang K, Hynan LS, Baskin F, Rosenberg RN: Platelet amyloid precursor protein processing: a bio-marker for Alzheimer's disease. J Neuro/ Sci 2006, 240(1-2):53-58.

103. Zubenko GS, Cohen BM, Boller F, Malinakova I, Keefe N, Chojnacki B: Platelet membrane abnormality in Alzheimer's disease. Ann Neurol 1987, 22(2):237-244

104. Zubenko GS, Brenner RP, Teply I: Risk factors for stroke as predictors of platelet membrane fluidity in Alzheimer's disease. Stroke 1991, 22(8): 997-1003.

105. Hajimohammadreza I, Brammer MJ, Eagger S, Burns A, Levy R: Platelet and erythrocyte membrane changes in Alzheimer's disease. Biochim Biophys Acta 1990, 1025(2):208-214.

106. Kanof PD, Mohs RC, Gross J, Davidson M, Bierer LM, Davis KL: Platelet phospholipid synthesis in Alzheimer's disease. Neurobiol Aging 1991, 12(1):65-69.

107. Piletz JE, Sarasua M, Whitehouse P, Chotani M: Intracellular membranes are more fluid in platelets of Alzheimer's disease patients. Neurobiol Aging 1991, 12(5):401-406.

108. Cohen BM, Zubenko GS, Babb SM: Abnormal platelet membrane composition in Alzheimer's-type dementia. Life Sci 1987, 40(25): 2445-2451.

109. Liu WW, Todd S, Coulson DT, Irvine GB, Passmore AP, McGuinness B, McConville M, Craig D, Johnston JA: A novel reciprocal and biphasic relationship between membrane cholesterol and beta-secretase activity in SH-SY5Y cells and in human platelets. J Neurochem 2009, 108(2): 341-349.

110. Grimm MO, Grimm HS, Pätzold AJ, Zinser EG, Halonen R, Duering M, Tschäpe JA, De Strooper B, Müller U, Shen J, Hartmann T: Regulation of cholesterol and sphingomyelin metabolism by amyloid-beta and presenilin. Nat Cell Biol 2005, 7(11):1118-1123.

111. Shimohama S, Fujimoto S, Matsushima H, Takenawa T, Taniguchi T, Perry G, Whitehouse PJ, Kimura J: Alteration of phospholipase C-delta protein level and specific activity in Alzheimer's disease. J Neurochem 1995, 64 (6):2629-2634

112. Matsushima H, Shimohama S, Fujimoto S, Takenawa T, Kimura J: Reduction of platelet phospholipase $\mathrm{C}$ activity in patients with Alzheimer disease. Alzheimer Dis Assoc Disord 1995, 9(4):213-217.

113. Matsushima H, Shimohama S, Kawamata J, Fujimoto S, Takenawa T, Kimura $\mathrm{J}$ : Reduction of platelet phospholipase C-delta1 activity in Alzheimer's disease associated with a specific apolipoprotein E genotype (epsilon3/ epsilon3). Int J Mol Med 1998, 1(1):91-93.

114. Balsinde J, Balboa MA, Insel PA, Dennis EA: Regulation and inhibition of phospholipase A2. Annu Rev Pharmacol Toxicol 1999, 39:175-189. Review.

115. Emmerling MR, Moore CJ, Doyle PD, Carroll RT, Davis RE: Phospholipase A2 activation influences the processing and secretion of the amyloid precursor protein. Biochem Biophys Res Commun 1993, 197(1):292-297.

116. Lehtonen JY, Holopainen JM, Kinnunen PK: Activation of phospholipase A2 by amyloid beta-peptides in vitro. Biochemistry 1996, 35(29):9407-9414.

117. Krzystanek E, Krzystanek M, Opala G, Trzeciak HI, Siuda J, Małecki A: Platelet phospholipase A2 activity in patients with Alzheimer's disease, vascular dementia and ischemic stroke. J Neural Transm 2007, 114(8):1033-1039.

118. Gattaz WF, Forlenza OV, Talib LL, Barbosa NR, Bottino CM: Platelet phospholipase $A(2)$ activity in Alzheimer's disease and mild cognitive impairment. J Neural Transm 2004, 111(5):591-601.

119. Gattaz WF, Cairns NJ, Levy R, Förstl H, Braus DF, Maras A: Decreased phospholipase A2 activity in the brain and in platelets of patients with Alzheimer's disease. Eur Arch Psychiatry Clin Neurosci 1996, 246(3):129-131.

120. Ross BM, Moszczynska A, Erlich J, Kish SJ: Phospholipid-metabolizing enzymes in Alzheimer's disease: increased lysophospholipid acyltransferase activity and decreased phospholipase A2 activity. J Neurochem 1998, 70(2):786-793.

121. Ebinger G, Bruyland M, Martin JJ, Herregodts $P$, Cras $Y$, Michotte $Y$, Gomme $L$ : Distribution of amines and their catabolities in brains from patients with Alzheimer's disease. J Neurolog Sci 1987, 77:267-283.

122. Palmer AM, Francis PT, Benton JS, Sims NR, Mann DM, Neary D, Snowden JS, Bowen DM: Presynaptic serotonergic dysfunction in patients with Alzheimer's disease. J Neurochem 1987, 48(1):8-15.

123. Tukiainen $\mathrm{E}$, Wikström J, Kilpeläinen $\mathrm{H}$ : Uptake of 5-hydroxytryptamine by blood platelets in Huntington's chorea and Alzheimer type of presenile dementia. Med Biol 1981, 59(2):116-120. 
124. Suranyi-Cadotte BE, Gauthier S, Lafaille F, DeFlores S, Dam TV, Nair NP, Quirion R: Platelet $3 \mathrm{H}$-imipramine binding distinguishes depression from Alzheimer dementia. Life Sci 1985, 37(24):2305-2311.

125. Arora RC, Emery OB, Meltzer HY: Serotonin uptake in the blood platelets of Alzheimer's disease patients. Neurology 1991, 41(8):1307-1309.

126. Sevush S, Jy W, Horstman LL, Mao WW, Kolodny L, Ahn YS: Platelet activation in Alzheimer disease. Arch Neurol 1998, 55(4):530-536.

127. Ciabattoni G, Porreca E, Di Febbo C, Di lorio A, Paganelli R, Bucciarelli T, Pescara L, Del Re L, Giusti C, Falco A, Sau A, Patrono C, Davì G: Determinants of platelet activation in Alzheimer's disease. Neurobiol Aging 2007, 28(3):336-342.

128. Muck-Seler D, Presecki P, Mimica N, Mustapic M, Pivac N, Babic A, Nedic G, Folnegovic-Smalc $V$ : Platelet serotonin concentration and monoamine oxidase type B activity in female patients in early, middle and late phase of Alzheimer's disease. Prog Neuropsychopharmacol Biol Psychiatry 2009, 33(7):1226-1231.

129. Adolfsson R, Gottfries CG, Oreland L, Wiberg A, Winblad B: Increased activity of brain and platelet monoamine oxidase in dementia of Alzheimer type. Life Sci 1980, 27(12):1029-1034.

130. Ahlskog JE, Uitti RJ, Tyce GM, O'Brien JF, Petersen RC, Kokmen E: Plasma catechols and monoamine oxidase metabolites in untreated Parkinson's and Alzheimer's diseases. J Neuro/ Sci 1996, 136(1-2):162-168.

131. Mimica N, Mück-Seler D, Pivac N, Mustapić M, Dezeljin M, Stipcević T, Presecki P, Radonić E, Folnegović-Smalc V: Platelet serotonin and monoamine oxidase in Alzheimer's disease with psychotic features. Coll Antropol 2008, 32(Suppl 1):119-122.

132. Mimica N, Muck-Seler D, Pivac N, Mustapic M, Folnegovic-Smalc V: Platelet serotonin and monoamine oxidase activity in patients with early-onset and late-onset of Alzheimer Disease. Period Biol 2005, 107:211-215.

133. Bermejo P, Martín-Aragón S, Benedí J, Susín C, Felici E, Gil P, Ribera JM, Villar AM: Differences of peripheral inflammatory markers between mild cognitive impairment and Alzheimer's disease. Immunol Lett 2008, 117(2):198-202.

134. Vignini A, Nanetti L, Moroni C, Tanase L, Bartolini M, Luzzi S, Provinciali L, Mazzanti $L$ : Modifications of platelet from Alzheimer disease patients: $a$ possible relation between membrane properties and NO metabolites. Neurobiol Aging 2007, 28(7):987-994.

135. Kawamoto EM, Munhoz CD, Glezer I, Bahia VS, Caramelli P, Nitrini R, Gorjão $R$, Curi R, Scavone C, Marcourakis T: Oxidative state in platelets and erythrocytes in aging and Alzheimer's disease. Neurobiol Aging 2005 26(6):857-864

136. Yu J, Jia JP: Platelet function in patients with Alzheimer disease: analysis of 40 cases. Zhonghua Yi Xue Za Zhi 2009, 89(3):183-186.

137. Rosenberg RN, Baskin F, Fosmire JA, Risser R, Adams P, Svetlik D, Honig LS, Cullum CM, Weiner MF: Altered amyloid protein processing in platelets of patients with Alzheimer disease. Arch Neurol 1997, 54(2):139-144.

138. Baskin F, Rosenberg RN, lyer L, Hynan L, Cullum CM: Platelet APP isoform ratios correlate with declining cognition in AD. Neurology 2000, 54(10):1907-1909.

139. Liu HC, Wang HC, Ko SY, Wang PN, Chi CW, Hong CJ, Lin KN, Liu TY: Correlation between platelet amyloid precursor protein isoform ratio and cognition in Alzheimer's disease. J Alzheimers Dis 2007, 11(1):77-84.

140. Di Luca M, Pastorino L, Cattabeni F, Zanardi R, Scarone S, Racagni G Smeraldi E, Perez J: Abnormal pattern of platelet APP isoforms in Alzheimer disease and Down syndrome. Arch Neurol 1996, 53(11):1162-1166.

141. Di Luca M, Pastorino L, Bianchetti A, Perez J, Vignolo LA, Lenzi GL, Trabucchi M, Cattabeni F, Padovani A: Differential level of platelet amyloid beta precursor protein isoforms: an early marker for Alzheimer disease. Arch Neurol 1998, 55(9):1195-1200.

142. Pastorino L, Colciaghi F, Marcon G, Borroni B, Cottini E, Cattabeni F, Padovani A, Di Luca M: Presenilin 2 mutation does not influence expression and concentration of APP forms in human platelets. Mol Med 2000, 6(10):816-824.

143. Padovani A, Borroni B, Colciaghi F, Pettenati C, Cottini E, Agosti C, Lenzi GL, Caltagirone C, Trabucchi M, Cattabeni F, Di Luca M: Abnormalities in the pattern of platelet amyloid precursor protein forms in patients with mild cognitive impairment and Alzheimer disease. Arch Neurol 2002, 59(1):71-75

144. Borroni B, Colciaghi F, Caltagirone C, Rozzini L, Broglio L, Cattabeni F, Di Luca M, Padovani A: Platelet amyloid precursor protein abnormalities in mild cognitive impairment predict conversion to dementia of Alzheimer type: a 2-year follow-up study. Arch Neurol 2003, 60(12):1740-1744.

145. Vignini A, Sartini D, Nanetti L, Luzzi S, Provinciali L, Mazzanti L, Emanuelli M: Platelet amyloid precursor protein isoform expression in Alzheimer's disease: evidence for peripheral marker. Int J Immunopathol Pharmacol 2011, 24(2):529-534.

doi:10.1186/1742-4933-9-20

Cite this article as: Catricala et al: Alzheimer disease and platelets: how's that relevant. Immunity \& Ageing 2012 9:20.

\section{Submit your next manuscript to BioMed Central and take full advantage of:}

- Convenient online submission

- Thorough peer review

- No space constraints or color figure charges

- Immediate publication on acceptance

- Inclusion in PubMed, CAS, Scopus and Google Scholar

- Research which is freely available for redistribution

Submit your manuscript at www.biomedcentral.com/submit
C BioMed Central 